\title{
Information Needs and Information Seeking Behaviour of the Physically Challenged: A Survey of Modupe Cole Memorial Child Care \& Treatment Home School Akoka, Lagos
}

\author{
Serah Funmilayo Oketunji DLS; BLS; MLS; PhD \\ Deputy Polytechnic Librarian, Yaba College of Technology, Yaba-Lagos \\ Ibidapo Oketunji BLS; MLS; PhD \\ Associate Professor, Department of Library and Information Science, \\ Adeleke University, Ede
}

doi: 10.19044/esj.2016.v12n31p400 URL:http://dx.doi.org/10.19044/esj.2016.v12n31p400

\begin{abstract}
Purpose The paper reports a study which investigated information needs and information seeking behaviour of physically challenged people. A literature review revealed a paucity of studies about the information-seeking behaviour of groups of people that are physically challenged. The study focused very specifically on both information needs and seeking behaviour of physically challenged at Modupe Memorial Home, Yaba Lagos.
\end{abstract}

Methodology The techniques for collecting qualitative data included two focus groups involving 45 participants and 15 individual interviewees, from the Home.

Findings The findings of the study address issues of information needs, information sources, the role of the library in meeting needs and the barriers to the use of the library.

Implication A major conclusion is that people who are physically challenged deserve to be provided with a range of ways of meeting their information needs, as are available for people that are not physically challenged.

Value Given the inexorable continuing impact of the information age, it is also concluded that ways must be found so that people with disabilities can participate equitably in the information economy.

Paper Type: Research

Keywords: Physically challenged, Information Needs, Information Seeking 


\section{Introduction}

Like other living organisms, human beings encounter perils during their lives, even during the time before birth. These dangers may threaten the health, disable, or even cause the death of people. In general, the origins of disabilities are: war, mal-nutrition, poverty, and lack of public health

People (whatever is the physical nature) need information for many reasons and therefore they are considered as information seeker regardless of age (Koren, 1998). Information is needed in all stages of human development but information seeking can often be an expensive and timeconsuming process. Time could be spent in sifting through irrelevant items to locate the required piece of information. Lucey (1995) indicates that relevant information increases knowledge, reduces uncertainty and is usable for the intended purpose. For the concept of information seeking behaviour to be properly appreciated, it is useful to introduce the concept of information seeking which, basically, is the consequence of a felt information need by a user who may then make demands upon formal and informal information sources or services to satisfy the need. Pao (1989) takes the point further and indicates that an information need is often the result of an unsolved problem; an individual realizes that his or her knowledge is insufficient to perform a given task. An information need, therefore, arises from an information problem, which comes when there is a gap in one's knowledge about something. Normally in such a situation, the information seeker feels uncertainty. Information need originates from the desire to know or to clear the uncertainty and that becomes a motivation which propels the problem into need. Put differently, information need arises when the state of possessed knowledge is less than that needed to deal with some issues (Haruna and Mabawonku, 2001).

Actions taken could include talking with peers, moderators, professionals and others who might prove to be helpful in determining the size and scope of the problem, understanding the nature of the information need, and finding a way to solve it (Kracker, 2002). There is a sense of relief and satisfaction if the search is successful or of anxiety and dissatisfaction if it is not successful (Kuhlthau, 1993).

For their daily survival, physically challenged people needs cover a wide variety of issues and concerns. A study done in 2001 by the World Bank revealed that major needs center around coping skills, physical and economic survival, and the ability to protect themselves from exploitation by both caregivers and community members. Other needs concern health and legal related issues, business skills, education, and the need to be cared for (World Bank, 2001). Although information has not been explicitly mentioned as a need, access to information underpins the ability to empower themselves for survival. 
Caregivers, who include organisations, or communities caring for physically challenge need guidance on where to find assistance. A study by UNICEF (2005) revealed that many orphans are not receiving enough grants due to them. This is partly due to the caregivers' ignorance on where to obtain information.

Yates (2004) identified several NGO's involved in service delivery to physically challenged and their caregivers and could see that their services concentrated mainly on six areas:

1. The provision of food by way of feeding schemes, soup kitchens and food parcels.

2. Assistance with education by providing uniforms, exempting school fees, paying for accommodation, etc.

3. Healthcare services, such as anti-retroviral compliance, fee exemption for basic health services, and nutritional monitoring.

4. Psychosocial support by way of home visits, organizing camps and clubs, training, counseling, and sport and recreation.

5. Teaching protection through life skills, information on rights, will writing and involvement in law reforms.

6. Providing general assistance through the teaching of income generating activities, access to grants, outreach programmes to caregivers, and temporary shelters and homes.

Most of these activities have (within them) information needs, and information provision and dissemination aspects that require to be investigated, understood and serviced to the benefit of the recipients.

Modupe Cole was established in 1960. It is a Home that provides vocational training and housing for about 170 physically and mentally challenged individuals. It houses adults and children ranging in age from ten years. The primary purpose was to empower the physically and mentally challenged. It also houses bedridden individuals and presently has over 45 such patients. Modupe Cole's approach to teach skills and trades provides individuals with the ability to earn a living and not be dependent on the kindness of strangers. Charity, in many cases, provides for the moment. The fact that it will be needed again necessitates a different game plan, like the enabling of the receiver to get on his own the where-with-all to meet his or her own needs. This is what empowers and it is empowerment in its' most basic form.

The home has eight departments designed to accomplish this task and each serves a viable purpose:

- Administrative

- Academic

- Vocational

- Clinics 
- Homes

- Transportation

- Security

- Kitchen

A library is provided under the academic department. This is located on site and it is filled with donated books to provide required information to all residents. The present study attempts to investigate how the library is prepared to meet their information needs.

The study focused on three categories of physically challenged handicapped students as follows:

- Blind or partially blind

- Deaf or partially deaf (with hearing impairment)

- People with mobility difficulties

\section{Statement of the Problem}

Very little is known about the techniques employed by the physically challenged people in a rehabilitation setting like when looking for information, the kinds of source formats they prefer to use and how these sources are used, what barriers they confront, how they feel about the process, and how they can be helped to better exploit the information resources available to them. Thus, the lack of research focussing on the information-seeking behaviour of this specific community group with disabilities calls for attention

\section{Purpose of the Study}

The purpose of this study was to examine the information needs of physically challenged and their caregivers at Modupe Cole Memorial Child Care \& Treatment Home School and to identify the information disseminating strategies used by the Librarian in managing the physically challenged situation in the Home.

The objectives of the study were as follows:

- To explored information sources consulted by the physically challenged to cope with situation

- To know the information channels available to the physically challenged when seeking information

- To identify and characterize the format of information available to them.

- To determine if the physically challenged are aware of library and information services provided in the home

- To know the type of challenges, face by the physically challenged in the search for information 
- To explore ways through which information services could be improved for them

\section{Research questions}

- Which information sources are consulted by the physically challenged to cope with their situation?

- Which information channels are available them when seeking information?

- What format of information sources do the physically challenged prefer in their search for information?

- What is the level of their awareness of library services in their home?

- What types of challenges face the physically challenged in their search for information?

- How should information services be improved to meet their needs?

\section{Assumption}

It is assumed that if information can be repackaged and made readily available for the physically challenged to exploit so that they can access information they need for their development in all spheres of life.

\section{Significance of the study}

The study was expected to create awareness to the physically challenged on how information, be it from the media such as radio, television, newspapers or books, from other people through workshops, conferences or social gatherings, can, improve their welfare.

For government and other service providers to intervene and be of assistance, knowledge and an understanding of the needs and environment of physically challenged and their caregivers are imperative to allow for effective service delivery planning. The basis of all service delivery is knowledge of the nature and extent of the problem at hand. This study it is hoped will highlights all areas of information needs of the physically challenged so that effective service delivery planning can be put in place by all governmental bodies concerned

This study is significant because it will reveal that under no circumstances can you find similar social aspects enjoyed by different people in terms of physical appearance even though the country is one and served by one government.

This study will create awareness to Government, especially the local Government, which is closer to this category of people so that they can redress any social issues which might still cause indifferences among people. Economically, this category of people lacks several resources which can help 
them develop and become better community inhabitants like the physically able people that are economically viable.

In practical terms, the study may reveal the differences between people. It exposed the researcher to a very poor setting where most of the inhabitants are information poor. This leads to the need of the establishment and the development of an information resource centre to be run by a professional information specialist. This resource centre will provide reliable information to such a community so that the access to and use of information for development can be improved upon.

\section{Scope and limitation of study}

The study was confined to Modupe Memorial Home, Yaba Lagos because of the time constraints of the course work. Certain criteria were employed to determine the selection of the study population. Residents who fitted the following criteria were interviewed:

They were either:

- $\quad$ totally blind or visually impaired;

- $\quad$ partially deaf or hearing impaired

- having mobility difficulties and,

- $\quad$ are currently registered at Modupe Home;

- $\quad$ utilised or required one or more of the library services made available at the Home to facilitate their learning

This study was conducted to investigate the extent to which library services was available and exploited by the physically challenged. It focussed only on Modupe Cole Memorial Child Care \& Treatment Home School. It was the researcher's assumption that only group of people fitted the scope of the study

Some of the information sources the researcher thought would be worthy to access were either not accessible or could only be accessed on certain times which could not be fitted on the researcher's schedule. Communication constituted a serious problem as some of the staffs to be interviewed are not always available because they live far away from the Home. This made the researcher to make repeated visits to the Home before necessary data were obtained

\section{Review of the Literature}

A review of relevant literature was conducted as a preliminary to the collection of data for this study. There is a scarcity of material which draws on first-hand information from users and in that respect this study covers fresh ground. Research that examines information provision for physically challenged people has been undertaken before. However, such studies have tended to focus on the information providers' perspective and many have not 
fully examined the opinions and needs of the user in depth. Moreover, they are not too plentiful. The needs of physically challenged people are met by a range of agencies in Nigeria. Studies may be focused on a provider and some of the smaller agencies may not have the resources to undertake major investigations. This may partly explain the relative scarcity of Nigerian based literature regarding the information needs of physically challenged people.

KOC University Library Glossary (2014) see information as data presented in readily comprehensible form, to which meaning has been attributed within a context for its use. In a more dynamic sense, the message is conveyed using a medium of communication or expression. Information is very vital to every human being, when demanded; it is usually expected to be put into use to solve a need. The nature of information is not easy to describe

The study of information needs and gathering behavior dates to 1948 when Bernal and others presented a paper on scientific information at the 1948 Royal Society conference (Bernal, 1960). During the past 30 years or so, a considerable body of literature has been produced dealing with information needs and information-seeking behavior of both individuals and groups in a variety of contexts (Anwar, Al-Ansari \& Abdullah, 2004). Information seeking behaviour deals with the psychological behaviour of the seeker. It involves the searching, locating, retrieving and using of information (Karunarathna, 2008).

An Information need is a gap in a person's knowledge. When a person identifies such a gap, it may be expressed as a question or a search query (LISWiki, 2015). Information needs leads to search and demand for information to meet the required gap.

The emphasis in information seeking behaviour in Information Science as observed by Ikoja-Odongo and Mostert (2006) can broadly be defined as that which is concerned with determining user's information needs, searching behaviour and subsequent use of information. Information seeking behaviour is, among others aspects, concerned with understanding how people seek and make use of information and the channels they use to get information. In a nutshell, information seeking behaviour can be viewed as activities directed towards obtaining information in response to an information need.

In a study on Library and Information Services to the virtually impaired: the role of academic libraries, Babalola and Haliso (2011) states that Libraries have a moral obligation to make information available to all categories of users regardless of their gender, age, race, political affiliation or disability but a lot of people have limited access to information materials most especially in developing countries like Nigeria. Per them a review of the literature shows that library and information services to the visually 
impaired in Nigeria is largely undertaken by Non-Governmental Organizations (NGOs). They concluded that access to information and knowledge has never been more critical than in the present information age and that those who lack access to essential information are excluded from participating actively in social, political, and economic activities. They stated further that the visually impaired, especially those living in the developing countries like Nigeria have been marginalized for too long because of the dearth of accessible materials. It is their opinion that that Nigerian academic libraries in collaboration with other stakeholders must stand up to their moral responsibility in ensuring an inclusive and equitable library and information services to the visually impaired

Atinmo (2007) expresses a view that in Nigeria, library and information services to the visually impaired are largely undertaken by NonGovernmental Organizations (NGOs). Per her, government intervention on the other is very minimal and focuses more on establishment of special education schools where teachers of physically handicapped children are trained rather than provision of library materials for the visually impaired.

During the last two decades, information needs of handicapped people regarding new information technologies have been considered. Hatter (1999) reported about making the web user-friendly for the blind and reported that in 1998 I.B.M. introduced talking version of "Home Page Reader" to help blind students have access to information sources more effectively. Kavanaugh (1999) reported that VISUNET: CANADA, a Canadian National network for the blind, has been established to help the blind to meet their information needs. Miller and Erazo (2000) list the websites which give information about the technologies which help handicapped people in using the libraries.

Williamson and Schaefer (2000) believe that inadequate research exists about information behaviour of people with disabilities (including the blind). In Nigeria, research on information needs and behaviour of the handicapped people in libraries, dates to 1970s, however, the published works in this subject are very few.

\section{Methodology}

This study is of a descriptive type and uses survey method. Purposive sampling method was employed for this study. The population under the study consisted of 300 residents in the home and stratification method was then employed to select units or observations in the sample. This study used individual (one-to-one) interviews, and a survey questionnaire to collect data from the physically challenged. Both the one-to-one interview and the group interview dealt with the same questions. A total of sixty physically challenged were interviewed. These two interviewing approaches were used 
to obtain more in-depth information from them, and the oral method of communication was deemed most appropriate because most could not see nor write.

Given the descriptive nature of the study, descriptive statistics of frequency counts was used to analyse the data. Research questions and the data relating to the study we grouped into appropriate categories. For all these, the Statistical Package for Social Sciences (SPSS) was used.

\section{Data Analysis and Findings}

Table 1: Sex of Respondent

\begin{tabular}{|ll|r|r|r|r|}
\hline \multicolumn{2}{|c|}{ Sex } & Frequency & Percent & Valid Percent & $\begin{array}{c}\text { Cumulative } \\
\text { Percent }\end{array}$ \\
\hline Valid & Male & 32 & 53.3 & 53.3 & 53.3 \\
& Female & 28 & 46.7 & 46.7 & 100.0 \\
& Total & 60 & 100.0 & 100.0 & \\
\hline
\end{tabular}

Thirty-two (53.4\%) of the respondents surveyed are males while twenty-eight (46.7\%) are females.

Table 2: Age of Respondent

\begin{tabular}{|ll|r|r|r|r|}
\hline \multicolumn{1}{|c|}{ Age } & Frequency & Percent & Valid Percent & $\begin{array}{c}\text { Cumulative } \\
\text { Percent }\end{array}$ \\
\hline Valid & 10-14years & 10 & 16.7 & 16.7 & 16.7 \\
& 15 & 25.0 & 25.0 & 41.7 \\
& 14-18years & 8 & 13.3 & 13.3 & 55.0 \\
19-23years & 12 & 20.0 & 20.0 & 75.0 \\
24-28years & 8 & 13.3 & 13.3 & 88.3 \\
& 29-33years & 7 & 11.7 & 11.7 & 100.0 \\
34years and above & 60 & 100.0 & 100.0 & \\
Total & & & \\
\hline
\end{tabular}

Ten (16.7\%) of the physically challenged are between the ages of 10 14 years, fifteen (25\%) are between 14-18 years, eight (13\%) are between 19-23years, twelve (20\%) are between $24-28$ years, eight $(13.3 \%)$ are between 29-33years while seven (11.7\%) are 34years and above. 
Table 3: Educational Background

\begin{tabular}{|c|c|c|c|c|c|}
\hline \multicolumn{2}{|c|}{ Educational Background } & \multirow{2}{*}{$\frac{\text { Frequency }}{10}$} & \multirow{2}{*}{$\frac{\text { Percent }}{16.7}$} & \multirow{2}{*}{$\frac{\text { Valid Percent }}{16.7}$} & \multirow{2}{*}{$\begin{array}{r}\begin{array}{c}\text { Cumulative } \\
\text { Percent }\end{array} \\
16.7\end{array}$} \\
\hline Valid & Attending primary school & & & & \\
\hline & $\begin{array}{l}\text { Attending secondary } \\
\text { school }\end{array}$ & 15 & 25.0 & 25.0 & 41.7 \\
\hline & $\begin{array}{l}\text { Completed secondary } \\
\text { school }\end{array}$ & 8 & 13.3 & 13.3 & 55.0 \\
\hline & Under Vocational training & 5 & 8.3 & 8.3 & 63.3 \\
\hline & $\begin{array}{l}\text { Completed Vocational } \\
\text { training }\end{array}$ & 22 & 36.7 & 36.7 & 100.0 \\
\hline & Total & 60 & 100.0 & 100.0 & \\
\hline
\end{tabular}

Their educational backgrounds ranged from first year in primary school to completion of vocational training. Ten (16.7\%) are presently attending primary school, fifteen (25\%) are attending secondary school, eight (13.3\%) have completed secondary school, five (8.3\%) are under vocational training while twenty-two (36.7\%) have completed vocational training.

Table 4: How long have you been staying in this home?

\begin{tabular}{|c|c|c|c|c|c|}
\hline \multicolumn{2}{|c|}{$\begin{array}{c}\text { Duration of stay in this } \\
\text { nome }\end{array}$} & \multirow{2}{*}{$\frac{\text { Frequency }}{19}$} & \multirow{2}{*}{$\frac{\text { Percent }}{31.7}$} & \multirow{2}{*}{$\frac{\text { Valid Percent }}{31.7}$} & \multirow{2}{*}{$\begin{array}{r}\begin{array}{c}\text { Cumulative } \\
\text { Percent }\end{array} \\
31.7\end{array}$} \\
\hline Valid & 5-10years & & & & \\
\hline & 11-15years & 15 & 25.0 & 25.0 & 56.7 \\
\hline & 15-20years & 11 & 18.3 & 18.3 & 75.0 \\
\hline & 21-25years & 10 & 16.7 & 16.7 & 91.7 \\
\hline & 26years and above & 5 & 8.3 & 8.3 & 100.0 \\
\hline & Total & 60 & 100.0 & 100.0 & \\
\hline
\end{tabular}

Nineteen (31.7\%) respondents have spent between 5-10years, fifteen (25\%) spent 11-15years, eleven (18.3\%) have spent between 15-20years, ten (16.7) have spent between 21-25years while five (8.3\%) spent 26years and above at the Home.

Table 5: What is your type of Challenge?

\begin{tabular}{|c|c|c|c|c|c|}
\hline \multicolumn{2}{|c|}{$\begin{array}{c}\text { Type of } \\
\text { Challenge }\end{array}$} & Frequency & Percent & Valid Percent & $\begin{array}{l}\text { Cumulative } \\
\text { Percent }\end{array}$ \\
\hline \multirow[t]{3}{*}{ Valid } & Blind & 12 & 20.0 & 20.0 & 20.0 \\
\hline & Others & 48 & 80.0 & 80.0 & 100.0 \\
\hline & Total & 60 & 100.0 & 100.0 & \\
\hline
\end{tabular}


Twelve (20\%) of the respondents are blind, while forty-eight (80\%) refers to the physically challenged with mobility difficulties and some with deafness or partial deafness.

Table 6: What Information Sources do you consult in the library

\begin{tabular}{|cc|r|r|r|r|}
\hline $\begin{array}{c}\text { Information Sources } \\
\text { consulted in the library }\end{array}$ & Frequency & Percent & Valid Percent & $\begin{array}{c}\text { Cumulative } \\
\text { Percent }\end{array}$ \\
\hline Valid & References sources & 23 & 38.3 & 38.3 & 38.3 \\
& Textbooks & 25 & 41.7 & 41.7 & 80.0 \\
& Periodicals & 8 & 13.3 & 13.3 & 93.3 \\
Audio Visual materials & 4 & 6.7 & 6.7 & 100.0 \\
Total & 60 & 100.0 & 100.0 & \\
\hline
\end{tabular}

Twenty- three (38\%) of the respondents prefer information on Reference sources, Twenty- five (41.7\%) prefer information using the Text book. Eight (13.3\%) prefer information consulting periodicals. Four (6.7\%) prefer to use Audio- Visual Aids

Table 7: What are Information Channels that are available to you?

\begin{tabular}{|c|c|c|c|c|c|}
\hline \multicolumn{2}{|c|}{$\begin{array}{c}\text { Available Information } \\
\text { Channels }\end{array}$} & Frequency & Percent & Valid Percent & $\begin{array}{l}\text { Cumulative } \\
\text { Percent }\end{array}$ \\
\hline \multirow[t]{4}{*}{ Valid } & Printed materials & 15 & 25.0 & 25.0 & 25.0 \\
\hline & Audio Visual & 26 & 43.3 & 43.3 & 68.3 \\
\hline & Verbal communication & 19 & 31.7 & 31.7 & 100.0 \\
\hline & Total & 60 & 100.0 & 100.0 & \\
\hline
\end{tabular}

Among the interview respondents, printed materials (25\%), Audio visual (43.3\%) and verbal communication (31.7\%) were identified as their main channels for accessing information

Table 8: What format of information do you prefer?

\begin{tabular}{|c|c|c|c|c|}
\hline $\begin{array}{l}\text { Information format } \\
\text { preferred }\end{array}$ & Frequency & Percent & Valid Percent & $\begin{array}{c}\text { Cumulative } \\
\text { Percent }\end{array}$ \\
\hline Print & 33 & 55.0 & 55.0 & 55.0 \\
\hline Audio Visual & 27 & 45.0 & 45.0 & 100.0 \\
\hline Total & 60 & 100.0 & 100.0 & \\
\hline
\end{tabular}

Table 8 summarises the data on the format of information preferred by the respondents where Prints is 55\%, Audio-visual is 45\%' 
Table 9: Which Information do you often find most useful?

\begin{tabular}{|c|c|c|c|c|}
\hline Information find most useful & Frequency & Percent & Valid Percent & $\begin{array}{l}\text { Cumulative } \\
\text { Percent }\end{array}$ \\
\hline $\begin{array}{ll}\text { Valid } & \text { financial assistance } \\
& \text { and grants }\end{array}$ & 16 & 26.7 & 26.7 & 26.7 \\
\hline $\begin{array}{l}\text { health services and } \\
\text { nutrition }\end{array}$ & 22 & 36.7 & 36.7 & 63.3 \\
\hline training opportunities & 15 & 25.0 & 25.0 & 88.3 \\
\hline $\begin{array}{l}\text { establishing small } \\
\text { businesses }\end{array}$ & 7 & 11.7 & 11.7 & 100.0 \\
\hline Total & 60 & 100.0 & 100.0 & \\
\hline
\end{tabular}

Table 9 indicates that Sixteen (26.7\%) respondents finds financial assistance and grants information most desirable, twenty -two (36.7\%) are interested in information relating to Health services and Nutrition. Fifteen (25\%) find Training opportunities as preferable, while Seven (11.7\%) information on establishing small businesses most useful

Table 10: Are you aware of the services that are provided in the library?

\begin{tabular}{|c|c|c|c|c|c|}
\hline \multicolumn{2}{|c|}{$\begin{array}{l}\text { Aware of } \\
\text { services }\end{array}$} & Frequency & Percent & Valid Percent & $\begin{array}{c}\text { Cumulative } \\
\text { Percent }\end{array}$ \\
\hline \multirow[t]{3}{*}{ Valid } & Yes & 47 & 78.3 & 78.3 & 78.3 \\
\hline & No & 13 & 21.7 & 21.7 & 100.0 \\
\hline & Total & 60 & 100.0 & 100.0 & \\
\hline
\end{tabular}

Forty- seven (78.3\%) of the respondents are fully aware of the services provided in the Library, while Thirteen (21.7\%) are not.

Table 11: How did you get to know about the services?

\begin{tabular}{|c|c|c|c|c|c|}
\hline \multicolumn{2}{|c|}{ Knowledge about the service } & Frequency & Percent & Valid Percent & $\begin{array}{l}\text { Cumulative } \\
\text { Percent }\end{array}$ \\
\hline \multirow[t]{3}{*}{$\overline{\text { Valid }}$} & Through Orientation & 35 & 58.3 & 58.3 & 58.3 \\
\hline & Announcement & 25 & 41.7 & 41.7 & 100.0 \\
\hline & Total & 60 & 100.0 & 100.0 & \\
\hline
\end{tabular}

Thirty-five (58.3\%) of the respondents claimed they got to know about the services through orientation, while the remaining group got to know through announcement 
Table 12: Challenge encountered when accessing the information needed

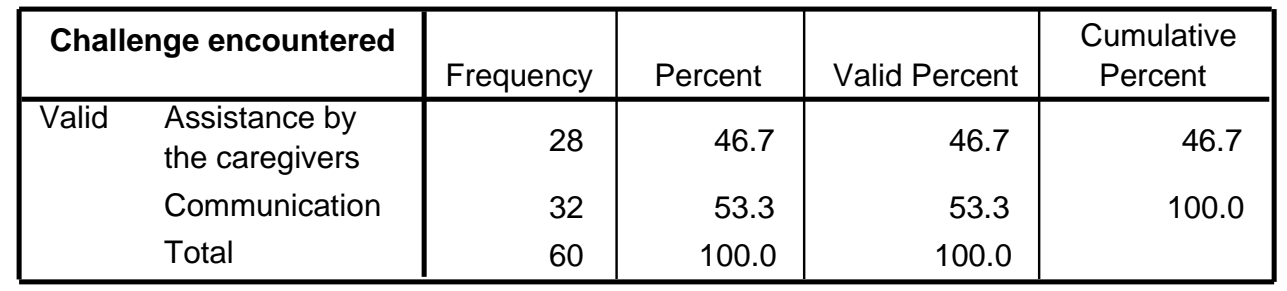

Table 12, When respondents were asked how they could solve problems related to information access, twenty -eight (46.7\%) said assistance were given them by the caregivers, while Thirty - two (53.3\%) said communication was their major constraint

Table 13: How do you think the flow of information could be improved

\begin{tabular}{|l|r|r|r|r|}
\hline \multicolumn{1}{|l|}{$\begin{array}{l}\text { Improvement on the flow of } \\
\text { information }\end{array}$} & Frequency & Percent & Valid Percent & $\begin{array}{c}\text { Cumulative } \\
\text { Percent }\end{array}$ \\
\hline Valid $\begin{array}{l}\text { Provision of Audio visual } \\
\text { aids }\end{array}$ & 24 & 40.0 & 40.0 & 40.0 \\
$\begin{array}{l}\text { Provision of automatic } \\
\text { speech recognition } \\
\text { machine }\end{array}$ & 22 & 36.7 & 36.7 & 76.7 \\
$\begin{array}{l}\text { Hearing impairment aids } \\
\text { Total }\end{array}$ & 14 & 23.3 & 23.3 & 100.0 \\
\hline
\end{tabular}

Table 13 reveals that Provision of Audio-visual aids would better improve the information flow with Twenty -four (40\%) respondents in agreement, while Twenty- two (36.7\%) agreed that provision of Automatic Speech Recognition machines will solve the problem and Fourteen (23.3\%) are of the view that Hearing Impairment Aids would improve the flow of information.

The important features of this research work are about information needs of the Physically Challenged and have been summarized under tables as represented in this study.

\section{Discussion of the Findings}

This study found that the information needs of the physically challenged are focused on addressing the difficult circumstances in which they live. Information for survival was cited as fundamental by them. This included information needs and provision on financial schemes from government and donor agencies, care support and health services. However, the mentioned 
items are seldom found in one place, making it a daunting task for people to get all the required information or to determine where to find it

The channels used for information access and dissemination differed slightly between the groups. The physically challenged preferred the mass media. It was found that despite all the channels available, there were still gaps in the flow of information to the physically challenged to the extent that many still did not know where to get the basic services provided by the Home

Most of the physically challenged thought that the information that they retrieved or accessed was helpful, although there was indication that not all the information was considered useful. This potentially leads to frustration and a feeling of helplessness in an already critical situation.

\section{Conclusion and Recommendations:}

A major way of improving services is for the librarian at the Home to strive to make information available in a manner and format suitable to the environment in which the physically challenged live, so that the information will reach them in a timely and effective manner. The preferences for different channels for accessing and disseminating information by the physically changed should be considered when attempting to provide them with information. It would also be ideal to empower/provide school teachers and physically challenged guardians with skills that will enable them to deal with physically challenged with informational socio and psychological problems, and avail them with basic information on the different services available to the physically challenged in their immediate environment and geographical area.

Furthermore, the physically challenged problem is a national problem; thus, there is a need to establish a national information strategy that can provide basic information to the physically challenged all over Nigeria to address their needs. This information could also be available on a website that radio stations and television stations could access and broadcast to the various stakeholders at the peak period of broadcasting hours.

\section{References:}

1. Anwar, M. A., Al-Ansari, H., \& Abdullah, A. (2004). Information seeking behaviour of Kuwaiti journalists. Libri 54 (4):228-236

2. Atinmo, M.A. (2000, July). Including the Excluded: The Challenges of Library and Information Services for visually handicapped readers in Nigeria in the new millennium. Paper presented at the International Special Education Congress, Manchester, UK. [Online] Available: http://webcache.googleusercontent.com/search?q=cache:X4kw0IJJ27 8J:www.cscanada.net/index.php/css/article/download/1224/1243+bab 
alola+and+haliso\&cd=1\&hl=en\&ct=clnk\&gl=uk\&source=www.goo gle.co.uk (Accessed on 04/07/2015)

3. Babalola, Yemisi $\mathrm{T}$ and Haliso, Yacob (2011). Library and Information Services to the Visually Impaired-The Role of Academic Libraries. Canadian Social Science

4. Vol. 7, No. 1, 2011, pp. 140-147. [Online] Available http://webcache.googleusercontent.com/search?q=cache:X4kw0IJJ27 8J:www.cscanada.net/index.php/css/article/download/1224/1243+bab alola + and + haliso \&cd $=1 \& \mathrm{hl}=\mathrm{en} \& \mathrm{ct}=\mathrm{clnk} \& \mathrm{gl}=\mathrm{uk} \&$ source $=$ www .goo gle.co.uk (Accessed on 04/07/2015)

5. Bernal, J. D. (1960). Scientific information and its users. ASLIB Proceedings12: 423-38.

6. Haruna, I. \& Mabawonku, I. (2001) Information needs and seeking behaviour of Legal practitioners and the challenges to law libraries in Lagos, Nigeria. International Information and Library Review, 33, 69-87.

7. Hattery, H. (1999). Making the web blind-user friendly: home-page reader and authority guidelines: Information retrieval and Library automation, 34(10), 1-3. [Online] Available http://webcache.googleusercontent.com/search?q=cache:1o14zVkaY n4J:crl.du.ac.in/ical09/papers/index_files/ical103_48_138_1_LE.pdf+research+on+information+needs+of+the+ph ysically+challenged\&hl=en\&gl=uk (Accessed 04/07/2015)

8. Ikoja-Odongo, J. R. and Mostert, J. 2006. Information seeking behaviour: a conceptual framework. South African of Libraries and Information Science 72(3): 145-158. [Online] Available http://webcache.googleusercontent.com/search?q=cache:fR37Qjqpw w8J:researchspace.ukzn.ac.za/xmlui/bitstream/handle/10413/563/sey amal_2009thesis.pdf?sequence\%3D1+Information+Needs+and+Infor mation+Seeking + Behaviour + of + disabled + children+in+NIgeria\&hl=e n\&gl=uk (Accessed 04/07/2015)

9. Karunarathna, A (2008). Information seeking behaviour of University Teachers in Sri Lanka in the field of management studies http://eprints.rclis.org/handle/10760/12699 (Accessed 21/11/2016)

10. LISWiki (2015). Information Need. Media Wiki. Retrieved from: http://liswiki.org/wiki/Information_need (Accessed 21/11/2016 )

11. Kavanagh, R. (1999). The virtual library for blind and visually impaired Canadians. Feliciter, 45(5), 296-9. [Online] Available http://webcache.googleusercontent.com/search?q=cache:1014zVkaY n4J:crl.du.ac.in/ical09/papers/index_files/ical103_48_138_1_LE.pdf+research+on+information+needs+of+the+ph ysically+challenged\&hl=en\&gl=uk (Accessed 04/072015) 
12. Koren, M. (1998). A global approach: the right to information. [Online] Available: http://www.ala.org/work/international/intlpprs/koren.html (Accessed: $04 / 08 / 2015)$

13. Kracker, J. (2002) Research anxiety and students' perceptions of research; an experiment. Part 1. Effect of teaching Kuhlthau's ISP model. Journal of the American Society for Information Science and Technology, 53 (4), 282-294. [Online] Available http://idv.sagepub.com/content/20/3/189 (Accessed 04/07/2015)

14. Kuhlthau, C. C. 1993. A principle of uncertainty for information seeking. Journal of Documentation 49(4): 339-355. [Online] Available

http://webcache.googleusercontent.com/search?q=cache:fR37Qjqpw w8J:researchspace.ukzn.ac.za/xmlui/bitstream/handle/10413/563/sey amal_2009thesis.pdf?sequence\%3D1+Information+Needs+and+Infor mation+Seeking + Behaviour+of+disabled+children+in+NIgeria\&hl=e $\mathrm{n} \& \mathrm{gl}=\mathrm{uk}$ (Accessed 04/07/2015)

15. Lucey, T. (1995) Management information systems. London: Pitman. [Online] Available http://idv.sagepub.com/content/20/3/189 (Accessed 04/08/2015)

16. Miller, and Erazo, E. (2005). Information access for users with disabilities. Library Issues: Briefings for Faculty and administrators. 20:5(May 2005). [Online] Available http://webcache.googleusercontent.com/search?q=cache:1o14zVkaY n4J:crl.du.ac.in/ical09/papers/index_files/ical103_48_138_1_LE.pdf+research+on+information+needs+of+the+ph ysically+challenged\&hl=en\&gl=uk (Accessed 04/09/2015)

17. Modupe Cole Memorial Child Care \& Treatment Home School. [Online] Available http://www.modupecolememorialchildcareths.org/ (Accessed 04/07/2015)

18. Pao, M.L. (1989) Concepts of information retrieval. Englewood: Libraries Unlimited. [Online] Available http://idv.sagepub.com/content/20/3/189 (Accessed 04/07/2015)

19. UNICEF (2005) Childhood under Threat in Namibia: A Supplement to the State of the World's Children Report 2005. UNICEF: Windhoek. [Online] Available http://findarticles.com/p/articles/mi_7002/is_1_19/ai_n32146506/pg 9/?tag=content;col1 (Accessed 04/07/2015)

20. Williamson, K., Schaude, D. and Bow, A. 2000. Information seeking by blind and sight impaired citizens: an ecological study. [Online] Available http://informationr.net/ir/5-4/paper79.html (Accessed 04/07/2015) 
21. World Bank (2001) Task Force for Child Survival and Development. [Online] Available http://www.taskforce.org/ (Accessed 04/07/2015)

22. Yates, D. (2004) Rapid Assessment, Analysis and Action Planning on Orphans and Vulnerable Children in Namibia. Windhoek: UNAIDS, UNICEF and USAID. [Online] Available http://findarticles.com/p/articles/mi_7002/is_1_19/ai_n32146506/pg_ 9/?tag=content;col1 (Accessed 04/07/2015) 